\title{
INKORPORASI OLEAT DAN EKSTRAK ANTOSIANIN PADA FILM GELATIN SEBAGAI INDIKATOR pH UNTUK KEMASAN PINTAR
}

\author{
[Incorporation of Oleic Acid and Anthocyanin in Gelatin Films as \\ $\mathrm{pH}$ Indicators for Intelligent Packaging]
}

\author{
Azis Boing Sitanggang ${ }^{1,2) \star}$, Muhammad Fakhrian Irsali ${ }^{1)}$, dan Saroat Rawdkeun ${ }^{3)}$ \\ 1) Departemen Ilmu dan Teknologi Pangan, Fakultas Teknologi Pertanian, Institut Pertanian Bogor, Bogor, Indonesia \\ 2) Southeast Asian Food and Agricultural Science and Technology (SEAFAST) Center, Institut Pertanian Bogor, Bogor, Indonesia \\ ${ }^{3)}$ Food Technology Program, School of Agro-Industry, Mae Fah Luang University, Chiang Rai 57100, Thailand
}

Diterima 27 Agustus 2019 / Disetujui 12 Mei 2020

\begin{abstract}
This study was aimed to develop and investigate the characteristics of the intelligent films made from gelatin with oleic acid $(O A)$ and anthocyanin extract incorporation. Anthocyanin was extracted from red cabbage (RC), sweet potato ( $S P)$, black bean coat seed (BB), and purple rice $(C R)$, and then tested for $\mathrm{pH}$ sensitivity. Anthocyanin from $S P$ was selected as it showed the highest $p H$ sensitivity. Gelatin film was incorporated with $20 \%$ of anthocyanin extract and $50 \%$ OA. The film s with OA and anthocyanin extracts incorporation was selected for application as the color changes can be observed clearly at pH 2-11. Red color was present on the film added with anthocyanin extract from SP. OA incorporation significantly decreased the elongation of the film, while it was on the contrary for anthocyanin extract incorporation. Both $O A$ and anthocyanin extracts incorporation decreased thickness, moisture content, and tensile strength of the film significantly $(P<0.05)$. Additionally, there was a reduction trend of water vapor permeability for gelatin film incorporated with $O A$ and anthocyanin. However, this reduction was insignificantly different with the control $(P>0.05)$. The incorporation of OA provided wavier surfaces while anthocyanin extract incorporation enhanced the compactness and smoothness of the film s, and provided smoother surfaces of the film. A higher enthalpy was needed for melting the film with anthocyanin extract.
\end{abstract}

Keywords: anthocyanin, biodegradable packaging, gelatin film, intelligent packaging, oleic acid

\begin{abstract}
ABSTRAK
Penelitian ini bertujuan mengembangkan dan menyelidiki karakteristik film cerdas dari gelatin dengan inkorporsai asam lemak oleat $(O A)$ dan ekstrak antosianin sebagai indikator alami. Antosianin diekstrak dari kol merah (RC), ubi jalar (SP), kacang hitam (BB), dan beras ungu (CR) kemudian diuji sensitivitas $\mathrm{pH}$. Antosianin dari SP dipilih sebagai indikator karena mampu menunjukkan sensitivitas $\mathrm{pH}$ tertinggi. Film gelatin diinkorporasikan dengan $20 \%$ ekstrak antosianin dan $50 \%$ asam oleat kemudian diuji karakteristiknya dengan kontrol dan film yang diinkorporasi OA atau ekstrak antosianin. Film dengan inkorporasi OA dan ekstrak antosianin dipilih karena dapat menunjukkan perubahan warna yang jelas pada $\mathrm{pH} 2-11$. Warna merah mendominasi pada film yang ditambahkan ekstrak antosianin. Penambahan OA pada film secara signifikan menurunkan elongasi film namun sebaliknya untuk penambahan ekstrak antosianin. Penambahan OA dan antosianin menurunkan ketebalan, kadar air, dan kekuatan tarik film secara signifikan $(P<0,05)$. Penurunan angka permeabilitas uap air terdapat pada film dengan inkorporasi OA walaupun tidak signifikan bila dibandingkan dengan kontrol $(P>0,05)$. As am oleat mem berikan permukaan yang lebih bergelombang sementara penambahan ekstrak antosianin meningkatkan kekompakan film dan memberikan permukaan yang lebih halus pada film. Entalpi yang lebih tinggi diperlukan untuk mencairkan film dengan ekstrak antosianin.
\end{abstract}

Kata kunci: antosianin, asam lemak oleat, film gelatin, kemasan biodegradable, kemasan pintar

*Penulis Korespondensi: E-mail: boing.lipan@apps.ipb.ac.id 


\section{PENDAHULUAN}

Pertumbuhan kebutuhan konsumen terhadap keamanan dan kualitas pangan saat ini mendorong proses pengembangan pengemasan pangan yang inovatif (Choi et al., 2017). Kemasan pintar atau intelligent packaging merupakan salah satu pengembangan lebih lanjut dari konsep pengemasan dalam aspek komunikasi. Kemasan pintar memiliki kemampuan untuk pemantauan secara langsung kondisi dari pangan tersebut melalui indikator internal dan eksternal (Robertson, 2013) Indikator yang digunakan, seperti label elektronik dan indikator diagnostik visual, umumnya ditempelkan, diinkorporasi, atau dicetak pada kemasan pangan tersebut sebagai sumber penyedia informasi terkait kualitas pangan selain tanggal kedaluwarsa yang tercetak pada kemasan pangan. Kemasan pintar harus bersifat sederhana namun dapat diterapkan secara efisien untuk menjamin bahwa produk dapat diterima oleh konsumen selama masa penyimpanannya (Pereira et al., 2015).

Selain pewarna sintetik (bromokresol ungu, bromokresol hijau, bromofenol biru, klorofenol merah, dan kresol merah), pewarna alami telah banyak dikaji dalam berbagai studi sebagai indikator $\mathrm{pH}$ (Balbinot-Alfaro et al., 2019). Sebagai hasil ekstrak dari sumber alami (umumnya nabati), pewarna alami bersifat terbarukan dan cenderung tidak toksik, serta lebih mudah untuk dibuat dibandingkan pewarna sintetik. Beberapa jenis zat warna alami telah dikembangkan dari berbagai sumber seperti kurkumin, antosianin, ekstrak aronia hitam (Aronia melanocarpa) dan lainnya (Prietto et al., 2017). Antosianin merupakan zat warna alami yang menarik perhatian para peneliti karena sifat perubahan strukturnya yang unik. Perubahan struktur ini bergantung pada kondisi $\mathrm{pH}$ dari larutan polar yang memengaruhi warnanya. Perubahan ini secara umum bersifat reversibel (Zhang et al., 2014). Penggunaan kemasan pintar berupa indikator $\mathrm{pH}$ telah banyak dikembangkan untuk menunjukkan kualitas bahan pangan secara aktual. Beberapa contohnya adalah film yang ditambahkan dengan metil merah dan bromokresol ungu digunakan untuk indikator penurunan kualitas daging; bromo-kresol hijau film digunakan untuk memverifikasi kerusakan filet ikan ikan melalui pelepasan amina yang mudah menguap; film dari pati jagung ataupun kitosan dengan penambahan antosianin telah umum digunakan untuk indikator terjadinya kebusukan dari produk-produk olahan daging (Balbinot-Alfaro et al., 2019).

Gelatin telah banyak digunakan sebagai biopolimer edible (dapat dimakan) karena mudah diperoleh melalui hidrolisis parsial dari jaringan hewani. Sifat gelatin yang mudah terurai menyebabkan gelatin banyak dipelajari dalam penerapannya untuk berbagai produk, salah satunya yaitu sebagai kom- ponen pengemasan pangan (Kaewprachu dan Rawdkuen, 2014). Namun, film gelatin yang bersifat hidrofilik memiliki sifat perlindungan yang kurang baik terhadap permeasi uap air. Komponen hidrofobik, seperti lemak dan minyak, dapat diinkorporasikan pada film untuk meningkatkan sifat ini (Tongnuanchan et al., 2015). Pengaruh inkorporasi lemak pada film dapat berupa perubahan tekstur film dan kinerja antosianin sebagai indikator $\mathrm{pH}$. Asam oleat memiliki potensi tersendiri sebagai salah satu komponen lipid yang digunakan. Meskipun memiliki pengaruh yang lebih sedikit terhadap peningkatan sifat perlindungan uap air pada film, asam oleat memberikan sifat transparansi, fleksibilitas, dan kehalusan yang lebih baik pada film dibandingkan dengan lemak yang tinggi akan asam lemak jenuh (Limpisophon et al., 2010). Penelitian ini bertujuan mengembangkan film gelatin sebagai kemasan pintar biodegradasi dengan inkorporasi asam lemak oleat dan ekstrak antosianin sebagai indikator alami dan menguji karakteristik fisik, kimia, dan mekanik dari film.

\section{BAHAN DAN METODE}

\section{Bahan}

Gelatin serbuk (commercial food grade bovine gelatin, Type B 150 bloom) dan Gliserol diperoleh dari Nutrition SC Co, Ltd. (Nakhenpathem, Thailand) dan Merck (Darmsstadt, Germany). Bahan kimia lain $(\mathrm{HCl}$, methanol, $\mathrm{NaOH}$, paraffin dan asam oleat) diperoleh dari Scientific and Technological Instruments Center Store, Mae Fah Luang University, Thailand. Kol merah (Brassica oleracea), ubi jalar ungu (Ipomoea batatas), beras merah Thailand (Oryza sativa L.), kacang hitam (Phaseolus vulgaris), ikan nila (Oreochromis niloticus), garam kasar, nasi, dan gula merah diperoleh dari pasar tradisional di Chiang Rai, Thailand.

\section{Pembuatan ekstrak antosianin}

Pengecilan ukuran sampel dilakukan dengan pemotongan kol merah (RC) dan ubi jalar ungu (SP), pengupasan dan perendaman kulit kacang hitam (BB), dan penghancuran beras merah Thailand (CR) dengan blender. Sampel ditimbang lalu dimaserasi dalam campuran $85 \mathrm{~mL}$ etanol $70 \%$ dan 15 $\mathrm{mL} 1 \mathrm{M} \mathrm{HCl}$ dengan rasio 1:10 (v/v) terhadap pelarut. Rendaman sampel disimpan selama 24 jam pada suhu $5^{\circ} \mathrm{C}$ dalam wadah gelap kemudian difiltrasi menggunakan kain kasa untuk memperoleh ekstrak antosianin.

\section{Pembuatan film gelatin (Faseha dan Rawdkuen, 2016)}

Larutan untuk pembuatan film dibuat dengan pencampuran gelatin serbuk dalam air destilata (to- 
tal protein dalam larutan 3\% b/v). Gliserol ditambahkan sebanyak $25 \% \mathrm{~b} / \mathrm{b}$ dari protein. Larutan film diinkubasi pada suhu $60^{\circ} \mathrm{C}$ selama 30 menit dengan sedikit pengadukan. Asam oleat dicampur dengan lesitin (25\% b/b asam oleat) ditambahkan sebanyak $50 \% \mathrm{~b} / \mathrm{b}$ protein dari larutan film. Larutan dihomogenisasi dengan ultra turrax homogenizer (IKA, USA) dengan kecepatan rotasi $5,000 \mathrm{rpm}$ selama $10 \mathrm{me}$ nit. Buih yang berlebih dipisahkan dengan sentrifugasi dengan kecepatan $6000 \mathrm{rpm}$ selama 5 menit pada suhu ruang. Antosianin ditambahkan sebanyak $20 \%$ dari total volume larutan yang dipersiapkan sebelumnya. Sekitar $4 \mathrm{~g}$ larutan film dituangkan pada cetakan silikon lalu dikeringkan selama 24 jam sebelum dimasukkan ke dalam humidity chamber (Binder, Germany) pada suhu $25 \pm 0,5^{\circ} \mathrm{C}$ dan kelembapan relatif (relative humidity, $\mathrm{RH}$ ) $50 \pm 5 \%$ selama 24 jam.

\section{Uji sensitivitas pH ekstrak dan film (Chaovanalikit et al., 2009)}

Pengaturan $\mathrm{pH} 20 \mathrm{~mL}$ ekstrak antosianin dilakukan dengan penambahan $1 \mathrm{~N} \mathrm{HCl}$ dan $1 \mathrm{~N} \mathrm{NaOH}$. Ekstrak lalu dipipet ke dalam 96-well microplate pada $\mathrm{pH}$ 2-12. Pengujian sensitivitas film dilakukan dengan pemotongan film berukuran $2 \times 2 \mathrm{~cm}^{2}$ dan direndam dalam cawan berisi larutan buffer $\mathrm{pH}$ 2-11.

\section{Uji warna film (Ibraheem et al., 2012)}

Penentuan warna film $\left(5 \times 5 \mathrm{~cm}^{2}\right)$ pada ruang warna CIELab dilakukan dengan colorimeter (Hunter Lab Color Quest XE) pada lima titik berbeda dengan tiga kali pengulangan. Mengacu pada, parameter yang diukur pada ruang warna CIELab yaitu tingkat keterangan $\left(L^{*}\right)$ dari hitam (0) hingga putih (100), tingkat kroma $\left(\mathrm{a}^{*}\right)$ antara hijau $\left(-\mathrm{a}^{*}\right)$ dan merah $\left(+a^{\star}\right)$, dan nilai warna atau hue $\left(b^{\star}\right)$ antara kuning $\left(+b^{*}\right)$ dan biru $\left(-b^{\star}\right)$. Ketebalan film $\left(2 \times 5 \mathrm{~cm}^{2}\right)$ diukur dengan mikrometer (Mitutoyo, Japan) pada 10 titik berbeda per sampel.

\section{Uji sifat mekanik film (Kaewprachu dan Rawdkuen, 2014)}

Film dikondisikan pada $\mathrm{RH} 50 \pm 5 \%$, suhu $25^{\circ} \mathrm{C}$, selama 48 jam sebelum daya regang dan sifat elongasi dari film diukur dengan universal testing machine (Instron 5566, Massachusets, USA) dengan panjang awal lembaran $3 \mathrm{~cm}$ dan kecepatan crosshead $30 \mathrm{~mm} /$ menit dengan sel beban $100 \mathrm{~N}$. Data dikalkulasikan dengan perumusan sebagai berikut:

$$
\text { Daya Regang }=\frac{\text { gaya maksimum }}{\text { lebar film } \times \text { ketebalan film }} \text {. }
$$

\author{
Sifat Elongasi $=$ \\ panjang pada gaya maksimum

$$
\text { panjang awal }
$$

\section{Uji kadar air (AOAC, 2012)}

Kadar air dihitung berdasarkan persentase kehilangan berat pada sampel setelah dikeringkan dalam oven pada suhu $105^{\circ} \mathrm{C}$ selama 24 jam terhadap bobot awal sampel.

\section{Uji permeabilitas uap air film (Chambi dan Grosso, 2011)}

Lembaran film diletakkan di atas wadah silinder berisi gel silika $(0 \% \mathrm{RH})$ dan direkatkan dengan parafin dan cincin logam. Wadah kemudian diletakkan di dalam humidity chamber pada suhu $25^{\circ} \mathrm{C}$ dan $\mathrm{RH}$ $50 \%$ dan ditimbang tiap setiap 1 jam dan pengamatan dilakukan selama 8 jam. Kalkulasi permeabilitas uap air (water vapor permeability, WVP) dari sampel dengan satuan $\mathrm{g} \cdot \mathrm{mm}^{-1} \cdot \mathrm{h}^{-1} \cdot \mathrm{cm}^{-2} \cdot \mathrm{Pa}^{-1}$ yaitu sebagai berikut:

$W V P=w \cdot x \cdot A^{-1} \cdot t^{-1} \cdot \Delta P^{-1}$

$\Delta \mathrm{P}=\mathrm{S}\left(\mathrm{R}_{1}-\mathrm{R}_{2}\right)$

dimana, $w$ merupakan perubahan bobot wadah (g), $x$ sebagai ketebalan film $(\mathrm{mm}), A$ sebagai area dari film $\left(\mathrm{cm}^{2}\right), t$ yaitu waktu interval $(\mathrm{h})$, dan $\Delta \mathrm{P}$ sebagai perbedaan tekanan uap air antara wadah sampel (dengan $\mathrm{RH}=\mathrm{R}_{2}$ ) dan chamber (dengan $\mathrm{RH}=\mathrm{R}_{1}$ ). Nilai $\Delta \mathrm{P}$ diperoleh dari pengalian tekanan uap air tersaturasi pada suhu $25^{\circ} \mathrm{C}(\mathrm{S}=3166 \mathrm{kPa})$ dengan selisih dari $\mathrm{RH}$ dalam wadah dan ruang penyimpanan. Penentuan nilai WVP dilakukan dalam tiga pengulangan per sampel.

\section{Uji komposisi spectrum infra merah film (Limpan et al., 2010)}

Spektroskopi infra merah pada sampel dilakukan dengan metode fourier transform infrared spectroscopy (FTIR) pada suhu ruang dengan pemindaian 64 kali pada resolusi $4 \mathrm{~cm}^{-1}$. Sampel diukur pada rentang 4000-650 $\mathrm{cm}^{-1}$ untuk menghindari tumpang tindih pada pita spektrum

\section{Uji sifat termal film (Pelissari et al., 2012)}

Sifat termal sampel dianalisis dengan metode differential scanning calorimetry (DSC, Mettler Toledo, Ohio, USA). Sekitar 2-5 mg sampel dalam pelat aluminium hermetis dipanaskan pada rentang suhu -60 sampai $150^{\circ} \mathrm{C}$ dengan laju pemanasan $10^{\circ} \mathrm{C} /$ menit dan pemberian gas nitrogen $(20 \mathrm{~mL} /$ menit). Pelat aluminium kosong digunakan sebagai referensi. 


\section{Pengamatan mikrostruktural film (Faseha dan} Rawdkeun, 2016)

Mikrostruktur film diamati dengan metode mikroskop pemindai electron (SEM, LEO/1450 VP, Carl Zeiss Microscopy GmbH, Jena, Germany). Sampel film dilapisi karbon dan diletakan pada penjepit sampel. Tegangan akselerasi (accelerating voltage) diatur pada 5,0 kV dan perbesaran 1000x pada permukaan film dan sayatan melintang dari film.

\section{HASIL DAN PEMBAHASAN}

\section{Sensitivitas ekstrak dan film terhadap perubahan pH}

Gambar 1 menunjukkan perubahan warna paling signifikan terjadi pada ekstrak RC dan SP pada $\mathrm{pH}$ 2-12. Ekstrak SP memiliki sensitivitas $\mathrm{pH}$ tertinggi, ditunjukkan oleh perbedaan warna pada $\mathrm{pH} 9$ dan 10 yang lebih signifikan dibandingkan ekstrak $\mathrm{RC}$, sehingga dipilih untuk penelitian ini. Perubahan warna serupa dari ekstrak ubi jalar ungu (SP) juga dilaporkan oleh Mahmudatussa'adah et al. (2014) dalam penelitiannya, terlepas dari jenis kultivarnya. Informasi ini menjadi dasar penggambaran perubahan struktur dari peonidin-3-(6"-kaffeoyl)-soforosida5-glikosida, bentuk umum antosianin dari ubi ungu. Warna ubi ungu yang dominan merah disebabkan oleh tingginya rasio peonidin terhadap sianidin $(>1)$. Peonindin membentuk warna magenta pada jaringan tumbuhan (Raghvendra et al., 2011). Perubahan warna pada film terlihat lebih jelas dengan inkorporasi asam oleat (Gambar 2). Film dengan ekstrak SP menunjukkan warna merah pada $\mathrm{pH} 2$ dan berkurang seiring dengan peningkatan $\mathrm{pH}$ hingga $\mathrm{pH} 5$. Warna berubah menjadi biru saat $\mathrm{pH}$ mencapai 6-9 dan perlahan berubah menjadi hijau pada $\mathrm{pH} 10 \mathrm{ke}$ atas. Film kontrol memiliki penampakan yang sama

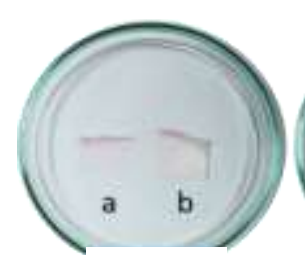

Kontrol
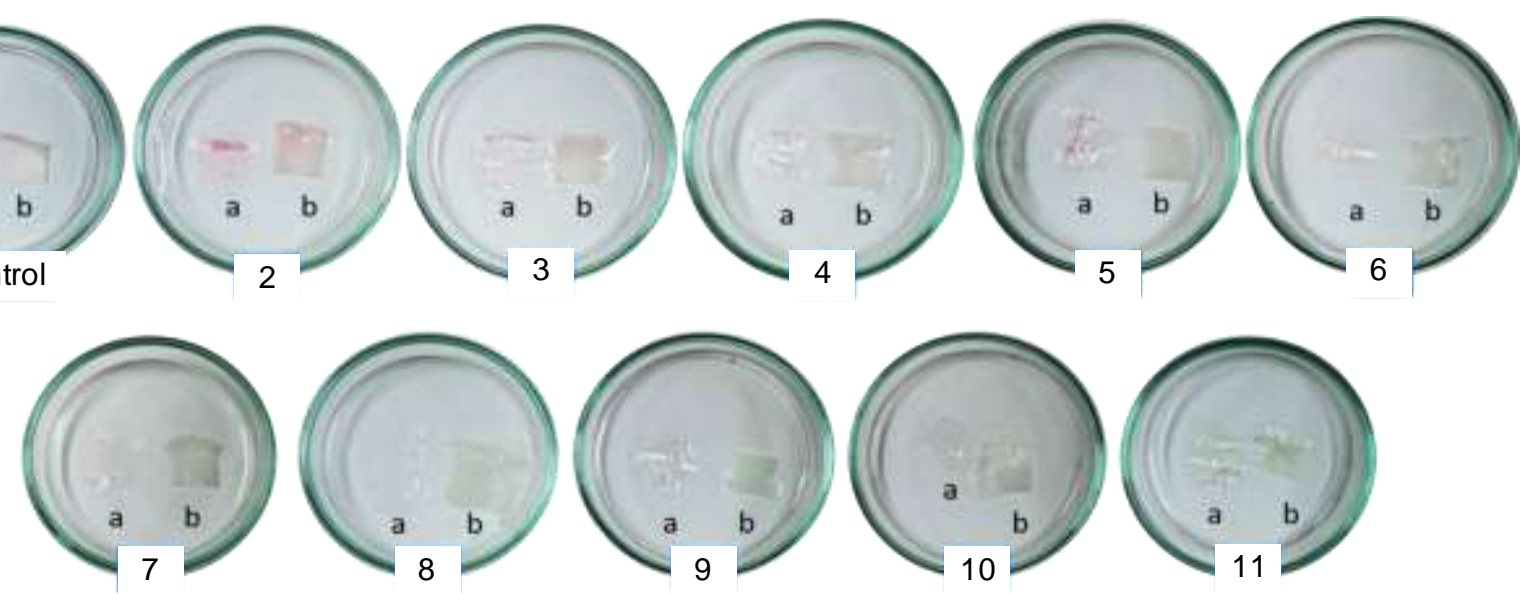

Gambar 2. Uji sensitivitas pH pada film dengan $20 \%$ ekstrak antosianin tanpa (a) dan dengan asam oleat (b) 


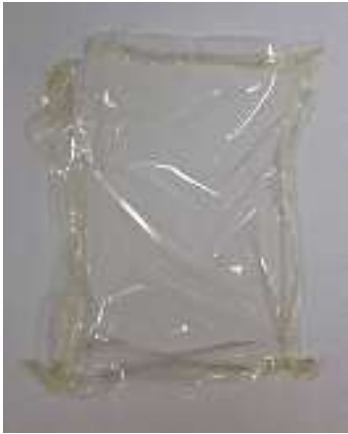

A

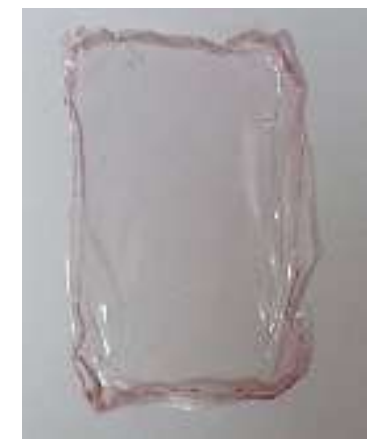

C

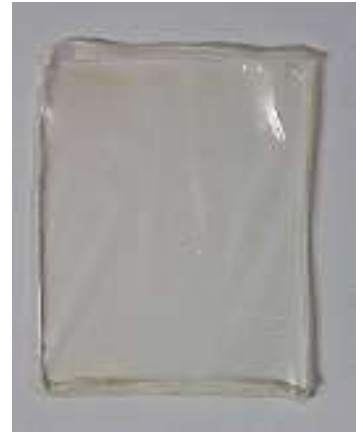

B

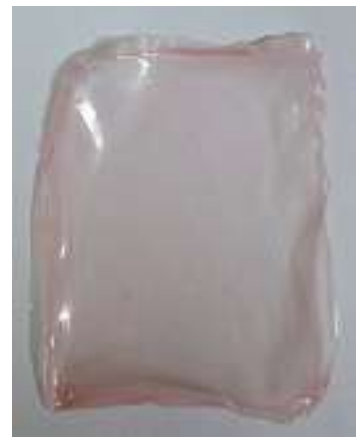

D
Keterangan: $A=$ Film gelatin kontrol tanpa inkorporasi $(G)$, $B=$ Film dengan inkorporasi asam oleat $(G O), C=$ Film dengan ekstrak antosianin (GA), $D=$ Film dengan inkorporasi asam oleat dan ekstrak antosianin (GOA)

Gambar 3. Bentuk film gelatin

Tabel 1. Hasil pengukuran warna pada sampel (ruang warna CIELab)

\begin{tabular}{lccc}
\hline Sampel & $\mathrm{L}^{*}$ & $\mathrm{a}^{*}$ & $\mathrm{~b}^{*}$ \\
\hline G & $92,12 \pm 0,15^{\mathrm{D}}$ & $-1,30 \pm 0,05^{\mathrm{D}}$ & $4,23 \pm 0,28^{\mathrm{D}}$ \\
GO & $93,36 \pm 0,09^{\mathrm{a}}$ & $-1,65 \pm 0,03^{\mathrm{D}}$ & $5,10 \pm 0,11^{\mathrm{a}}$ \\
GA & $87,57 \pm 0,32^{\mathrm{a}}$ & $6,38 \pm 0,36^{\mathrm{a}}$ & $1,01 \pm 0,03^{\mathrm{a}}$ \\
GOA & $88,49 \pm 0,53^{\mathrm{c}}$ & $5,98 \pm 0,53^{\mathrm{a}}$ & $2,88 \pm 0,10^{\mathrm{c}}$ \\
\hline
\end{tabular}

Keterangan:Data dipresentasikan dalam bentuk rata-rata \pm standar deviasi. Perbedaan superskrip pada data $(\mathrm{n}=3)$ menunjukkan data berbeda secara signifikan $(P<0,05) . \mathrm{G}=$ film kontrol; $\mathrm{GO}=$ film dengan asam oleat; $\mathrm{GA}=$ film dengan ekstrak antosianin; $\mathrm{GOA}=$ film dengan asam oleat dan ekstrak antosianin

\section{Sifat mekanik film}

Data ketebalan, daya regang, dan elongasi film disajikan pada Tabel 2. Film dengan penambahan asam oleat dan ekstrak antosianin memiliki ketebalan tertinggi (Wang et al., 2014). Penambahan asam lemak dan pewarna pada larutan etanol-air berkontribusi pada peningkatan ketebalan pada film gelatin (Musso et al., 2017). Daya regang dan elongasi film menurun saat film ditambahkan asam oleat sedangkan penambahan ekstrak antosianin meningkatkan sifat elongasi dari film. Penambahan antosianin pada film dapat memfasilitasi mobilitas rantai senyawa pembentuk struktur film serta penurunan $\mathrm{pH}$ film yang mengakibatkan depolimerasi gelatin (Stoll, 2015). Kedua faktor ini dapat meningkatkan sifat plastis dari film yang dihasilkan. Pengurangan daya regang dapat dikaitkan dengan rendahnya kohesi dalam jaringan biopolimer yang disebabkan kecenderungan fase lipida untuk menghambat pembentukan ikatan intermolekuler antar protein (RoccaSmith et al., 2016). Penambahan antosianin dalam etanol-HCl pada larutan film juga berkontribusi terhadap penurunan kepadatan film akibat perbedaan dari pembukaan rantai molekuler atau ikatan silang antar jaringan protein (Denavi et al., 2009).

Tabel 2. Ketebalan dan sifat mekanik dari film

\begin{tabular}{lccc}
\hline Sampel & $\begin{array}{c}\text { Ketebalan } \\
(\mu \mathrm{m})\end{array}$ & $\begin{array}{c}\text { Daya Regang } \\
(\mathrm{MPa})\end{array}$ & $\begin{array}{c}\text { Elongasi } \\
(\%)\end{array}$ \\
\hline \multirow{2}{*}{$\mathrm{G}$} & $46,11 \pm$ & $1,2592 \pm 0,3162^{\mathrm{a}}$ & $199,44 \pm$ \\
& $2,34^{\mathrm{d}}$ & & $12,29^{\mathrm{bc}}$ \\
$\mathrm{GO}$ & $61,30 \pm$ & $1,2081 \pm 0,4357^{\mathrm{a}}$ & $175,56 \pm$ \\
& $2,99^{\mathrm{b}}$ & & $22,19^{\mathrm{c}}$ \\
$\mathrm{GA}$ & $50,28 \pm$ & $0,5393 \pm 0,4221^{\mathrm{D}}$ & $164,44 \pm$ \\
& $4,57^{\mathrm{c}}$ & & $34,57^{\mathrm{a}}$ \\
GOA & $68,38 \pm$ & $0,5230 \pm 0,0667^{\mathrm{D}}$ & $141,11 \pm$ \\
& $5,95^{\mathrm{a}}$ & & $42,57^{\mathrm{ab}}$ \\
\hline
\end{tabular}

Keterangan: Data dipresentasikan dalam bentuk ratarata \pm standar deviasi. Perbedaan superskrip pada data $(\mathrm{n}=3$, untuk ketebalan film $\mathrm{n}=10$ ) menunjukkan data berbeda secara signifikan $(P<0,05) . \mathrm{G}=$ film kontrol; $\mathrm{GO}=$ film dengan as am oleat; $\mathrm{GA}=$ film dengan ekstrak antosianin; $\mathrm{GOA}=$ film dengan asam oleat dan ekstrak antosianin

\section{Kadar air dan sifat permeabilitas uap air pada film}

Kadar air dan sifat permeabilitas uap air dari film dapat dilihat pada Tabel 3. Penambahan asam oleat dan ekstrak antosianin secara signifikan mengurangi kadar air pada film. Adanya perubahan interaksi protein-air parsial dengan protein-lipid dan ikatan hidrofobik yang dibentuk dari interaksi protein dengan antosianin menyebabkan penurunan kadar air pada film (Ma et al., 2012a; Kaewprachu et al., 2017). Penambahan asam oleat dan ekstrak antosianin tidak berpengaruh secara signifikan terhadap sifat perlindungan uap air pada film $(P>0,05)$. Meskipun demikian, penurunan permeabilitas uap air terjadi pada film dengan asam oleat, dengan atau tanpa penambahan ekstrak, bila dibandingkan dengan kontrol. Hal ini mengindikasikan potensi asam oleat sebagai komponen yang membantu meningkatkan sifat proteksi terhadap permeabiitas uap air pada konsentrasi yang lebih tinggi. Potensi ini juga didukung oleh penampakan asam oleat yang lebih jernih dibandingkan dengan lipid yang tinggi asam lemak jenuh (Bourtoom dan Chinnan, 2009). Penyeragaman globula asam oleat pada matriks film dapat meningkatkan sifat perlindungan film serta mengurangi adsorpsi dan difusi air dalam matriks film. 
Penggunaan microfluidizer atau gelombang suara ultra dapat diaplikasikan dalam proses homogenisasi larutan film untuk membantu memperbaiki sifat ini (Ma et al., 2012b). Dalam studi oleh Tongnuanchan et al. (2013), film berbasis emulsi yang ditambahkan lesitin kedelai memiliki WVP terendah. $\mathrm{Pe}$ nambahan lesitin mampu menstabilkan dan memudahkan fase minyak untuk menyebar secara merata pada matriks film. Selain pengembangan pada metode homogenisasi larutan, visualisasi dengan confocal scanning laser microscopy (CSLM) dapat dilakukan untuk memantau distribusi globula pada film.

Tabel 3. Kadar air dan permeabilitas uap air pada film

\begin{tabular}{lcc}
\hline Sampel & Kadar Air (\%) & $\begin{array}{c}\text { Permeabilitas Uap Air }\left(10^{-6}\right. \\
\left.\mathrm{g} \mathrm{m} \mathrm{m} \mathrm{h}^{-1} \mathrm{~cm}^{-2} \mathrm{~Pa}^{-1}\right)\end{array}$ \\
\hline G & $41,22 \pm 0,23^{\mathrm{a}}$ & $17,0015 \pm 2,4218^{\mathrm{a}}$ \\
GO & $36,50 \pm 0,34^{\mathrm{c}}$ & $13,6736 \pm 0,4022^{\mathrm{a}}$ \\
GA & $39,38 \pm 0,51^{\mathrm{D}}$ & $17,1215 \pm 5,4306^{\mathrm{a}}$ \\
GOA & $33,61 \pm 0,25^{\mathrm{a}}$ & $16,6127 \pm 0,4216^{\mathrm{a}}$
\end{tabular}

Keterangan: Data dipresentasikan dalam bentuk ratarata \pm standar deviasi. Perbedaan superskrip pada data $(n=3$, untuk ketebalan film $n=10)$ menunjukkan data berbeda secara signifikan $(P<0,05)$. G= film kontrol; $\mathrm{GO}=$ film dengan as am oleat; $\mathrm{GA}=$ film dengan ekstrak antosianin;GOA= film dengan asam oleat dan ekstrak antosianin

\section{Spektrum infra merah film}

Gambar 4 menunjukkan spektrum FTIR pada sampel dengan pola yang sama, menunjukkan tidak adanya perubahan signifikan dalam kelompok fungsional film. Pembentukan puncak pada $3279,82-$ $3283,41, \quad 1629,06-1630,83, \quad 1537,83-1544,09$, dan 1233,25-1237,50 merujuk pada amida-A, amida I, amida II, dan amida III (Pradini et al., 2018). Puncak yang terbentuk pada $1032,34-1035,45 \mathrm{~cm}^{-}{ }^{1}$ di semua spektrum berasal dari gugus $\mathrm{OH}$ dari gliserol yang digunakan sebagai plasticizer (Tongnuanchan et al., 2015).

Penambahan asam oleat dan ekstrak antosianin ke film meningkatkan pergeseran puncak dan intensitas di daerah amida dan area di panjang gelombang sekitar $1032-1036 \mathrm{~cm}^{-1}$. Hal ini mungkin disebabkan oleh peningkatan interaksi ikatan hidrogen dari gugus hidroksil dari ekstrak antosianin dengan protein, ikatan ionik tautan silang antara gugus karboksil yang berasal dari asam oleat dengan asam amino, dan ikatan disulfit (Hanani et al., 2012). Penurunan puncak pada sampel yang hanya ditambahkan dengan asam oleat atau ekstrak antosianin mungkin menandakan berkurangnya interaksi tersebut, mengarah pada pemisahan polimer protein yang lebih cenderung terhadap interaksi antar protein (Ma et al., 2016).

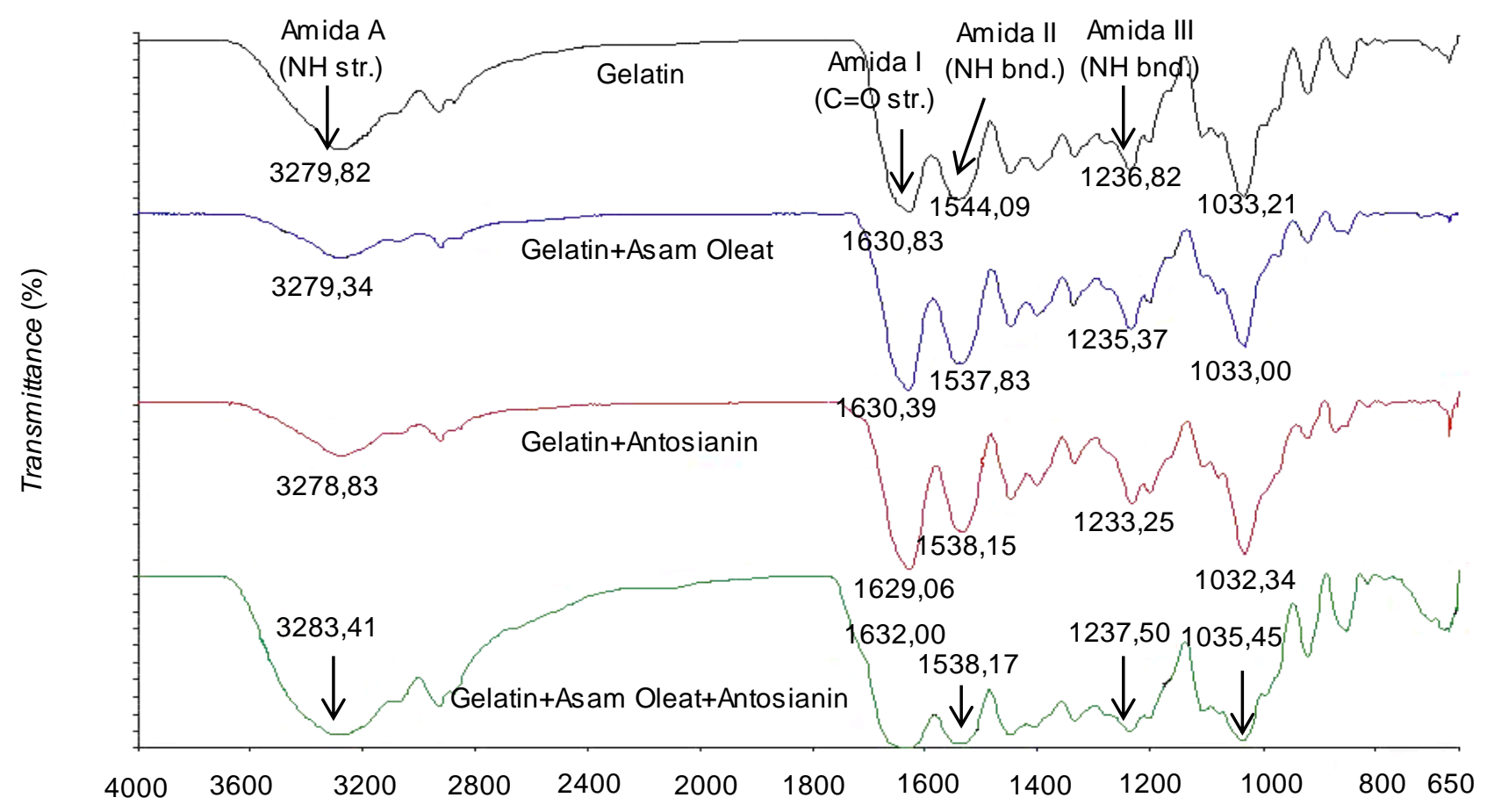

Wavenumber $\mathrm{cm}^{-1}$

Gambar 4. Kurva spektrum FTIR dari film 


\section{Sifat termal film}

Dua daerah sinyal endotermik terbentuk pada termogram sampel dengan penambahan asam oleat (Gambar 5), menunjukkan proses pelelehan fase minyak pada suhu rendah dan protein pada suhu yang lebih tinggi (Tongnuanchan et al., 2015). Film dengan penambahan asam oleat membentuk sinyal pada suhu, dengan dan tanpa ekstrak, 5,17 dan $8,00^{\circ} \mathrm{C}$. Pelelehan fase protein terjadi pada semua sampel film pada suhu $78,50-99,83^{\circ} \mathrm{C}$. Pembentukan dua sinyal serta pelelehan fase protein pada suhu yang lebih rendah menunjukkan sifat asam oleat sebagai senyawa non-homogen pada matriks film (Ma et al., 2012b). Mengacu pada Tabel 4, sampel dengan asam oleat dan ekstrak antosianin menampilkan entalpi endotermik yang lebih tinggi dibandingkan dengan sampel tanpa ekstrak. Hal ini mungkin mengindikasikan entalpi yang lebih tinggi dibutuhkan untuk pelelehan globula lipid akibat adanya gangguan dari ikatan hidrogen dari ekstrak antosianin (Luchese et al., 2018). Tongnuanchan et al. (2015) menjelaskan bahwa peningkatan persentase lipid yang ditambahkan dapat mempertahankan fase minyak pada matriks film dalam bentuk fase beraturan (ordered phase) yang lebih kuat dengan molekul gelatin.

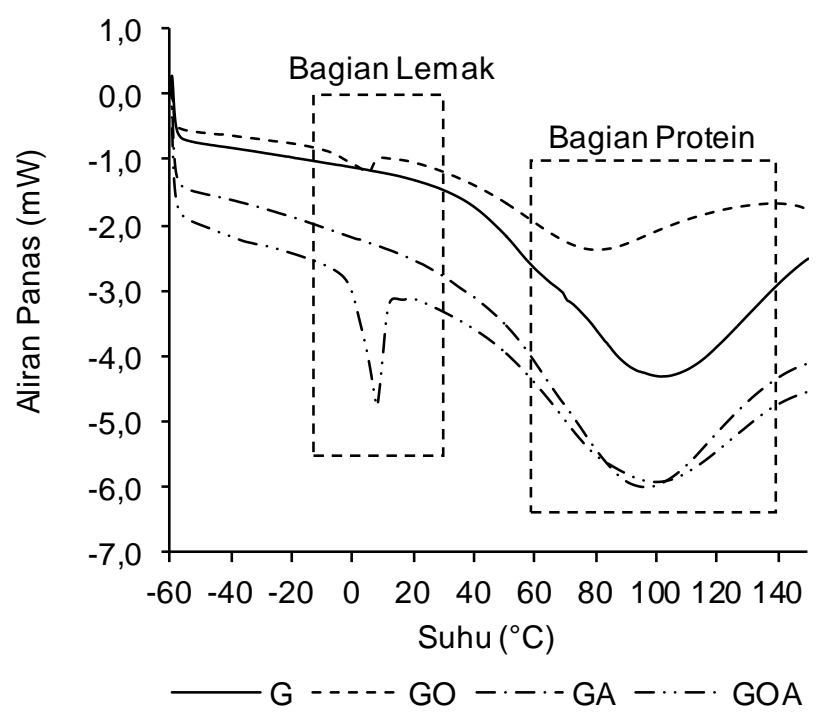

Gambar 5. Kurva analisis differential scanning calorimetry (DSC) dari film kontrol (G) dan film dengan inkorporasi asam oleat (GO), ekstrak antosianin (GA), dan keduanya (GOA)

Penurunan suhu leleh dari fase protein dapat dilihat pada sampel dengan asam oleat. Ini berkebalikan dengan hasil studi oleh Ma et al. (2012a) yakni penambahan asam oleat berkorelasi positif dengan kenaikan suhu leleh dari film. Entalpi endotermik tertinggi diamati pada puncak kedua sampel dengan ekstrak antosianin, mengindikasikan adanya tambahan energi yang diserap saat proses pelelehan film. Energi ini diperlukan untuk pemutusan ikatan hidrogen serta ikatan intermolekul dan intramolekul lainnya dan pelepasan molekul air yang terikat pada matriks, selain untuk pembukaan struktur kristalin triple-helix dari gelatin (Pereira et al., 2015). Perubahan dari interaksi intermolekuler dan intramolekuler pada film akibat penambahan komponen yang tinggi akan polifenol juga dilaporkan dalam beberapa studi (Rattaya et al., 2009; Kadam et al., 2015).

Tabel 4. Data analisis differential scanning calorimetry (DSC) pada film

\begin{tabular}{lcccc}
\hline & \multicolumn{2}{c}{$\begin{array}{c}\text { Puncak 1 (Fase } \\
\text { Lemak) }\end{array}$} & \multicolumn{2}{c}{ Puncak 2 (Fase } \\
Sampel & \multicolumn{2}{c}{ Protein) } \\
\cline { 2 - 5 } & $\begin{array}{c}\text { Tpuncak } \\
\left({ }^{\circ} \mathrm{C}\right)\end{array}$ & $\begin{array}{c}\text { Entalpi } \\
(\mathrm{J} / \mathrm{g})\end{array}$ & $\begin{array}{c}\text { Tpuncak } \\
\left({ }^{\circ} \mathrm{C}\right)\end{array}$ & $\begin{array}{c}\text { Entalpi } \\
(\mathrm{J} / \mathrm{g})\end{array}$ \\
\hline $\mathrm{G}$ & n.d. & n.d. & 99,17 & $-150,29$ \\
$\mathrm{GO}$ & 5,17 & $-6,08$ & 78,50 & $-153,17$ \\
$\mathrm{GA}$ & n.d. & n.d. & 93,50 & $-181,23$ \\
$\mathrm{GOA}$ & 8,00 & $-13,40$ & 99,83 & $-125,35$ \\
\hline
\end{tabular}

Keterangan: n.d: tidak terdeteksi (not detected); G: film kontrol; GO: film dengan asam oleat; GA: film dengan ekstrak antosianin; GOA: film dengan asam oleat dan ekstrak antosianin; - : tidak terdeteksi

\section{Mikrostruktur film}

Gambar 6 menunjukkan penampakan mikroskopik dari permukaan dan sayatan melintang dari film. Film dengan asam oleat memiliki struktur yang tidak beraturan, dengan atau tanpa penambahan antosianin. Namun, penambahan asam oleat meningkatkan ketebalan dari film. Pembentukan globula minyak pada permukaan dan gelembung udara yang terperangkap berkontribusi pada pembentukan mikrostruktur film yang bergelombang (Limpisophon et al., 2010). Aplikasi proses homogenisasi berkecepatan atau berfrekuensi lebih tinggi, seperti pada homogenisasi ultrasonik, atau modifikasi pada parameter lain seperti peningkatan tekanan saat proses homogenisasi mungkin dapat memperbaiki kehalusan film dengan menurunkan ukuran globula minyak yang terbentuk dan meningkatkan penyebarannya secara homogen dalam matriks film (Kaci et al., 2017). Film dengan penambahan ekstrak antosianin memiliki permukaan yang lebih halus dan padat serta struktur yang elastis. Pembentukan struktur yang lebih kompak pada film dengan ekstrak antosianin berkaitan dengan interaksi intermolekuler antara antosianin dengan jaringan protein dalam film gelatin (Wang et al., 2012). 


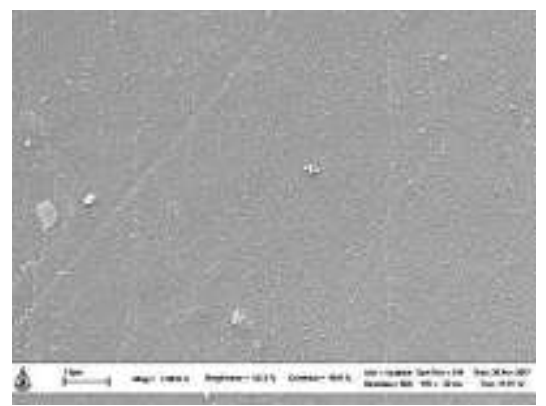

$1 \mathrm{~A}$

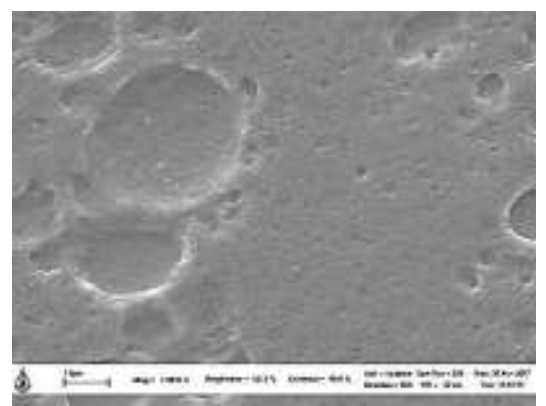

1D

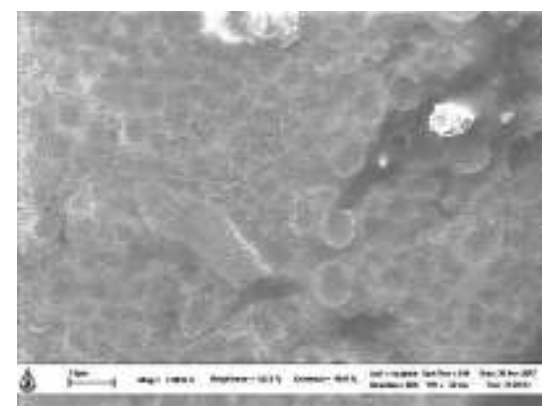

1B

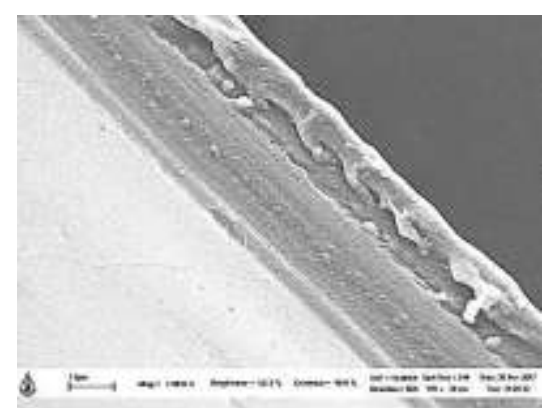

2A

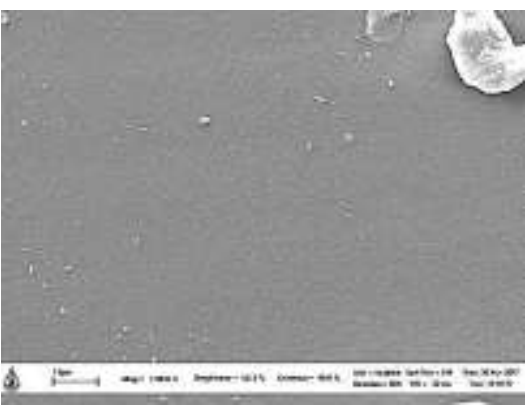

$1 \mathrm{C}$

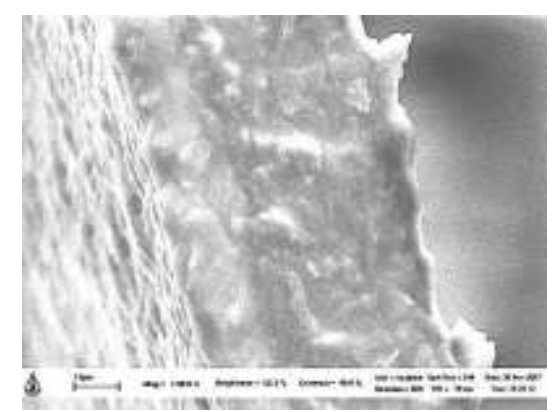

2B

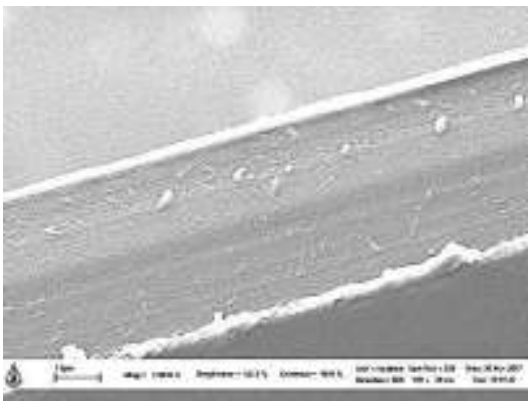

2C

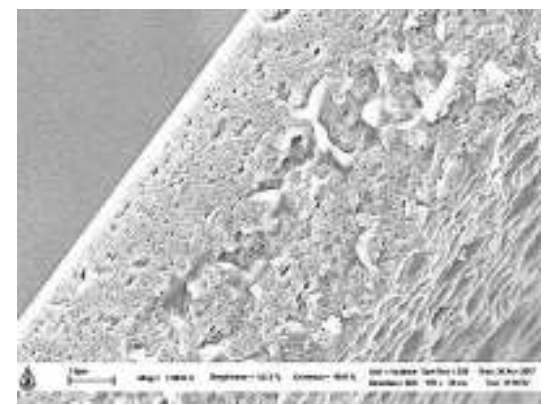

2D

Gambar 6. Mikrograf dari permukaan (1) dan sayatan melintang (2) dari film gelatin kontrol (A) dan film dengan inkorporasi asam oleat (B), ekstrak antosianin (C), dan keduanya (D)

\section{KESIMPULAN}

Antosianin dari ubi ungu (SP) memberikan sensitivitas $\mathrm{pH}$ tertinggi dan digunakan sebagai indikator dalam penelitian ini. Film dengan asam oleat dan ekstrak antosianin SP menunjukkan perubahan warna yang paling signifikan pada $\mathrm{pH} 2-11$. Inkorporasi asam oleat pada film memengaruhi warna, khususnya kuning, dan kecerahan film. Namun, pengaruh ini lebih kecil bila dibandingkan dengan inkorporasi lipid yang kaya asam lemak jenuh. Warna merah mendominasi pada film dengan ekstrak antosianin dari SP. Inkorporasi asam oleat secara signifikan menurunkan sifat elongasi dari film namun sebaliknya dengan inkorporasi ekstrak. Inkorporasi asam oleat dan ekstrak antosianin menurunkan ketebalan, kadar air, dan kekuatan tarik dari film secara signifikan. Permeabilitas uap air film tidak berubah secara signifikan dengan semua perlakuan walaupun penurunan terjadi dengan adanya penambahan asam oleat. Penambahan asam oleat dan ekstrak antosianin memiliki pengaruh yang nyata terhadap sifat termal film gelatin. Entalpi yang lebih tinggi diperlukan untuk melelehkan film dengan ekstrak antosianin. Asam oleat memberikan permukaan bergelombang pada film dan penggabungan ekstrak antosianin menghasilkan permukaan film yang lebih halus dan kompak. Studi lebih lanjut diperlukan untuk mengembangkan metode homogenisasi, formulasi berkaitan dengan komposisi asam oleat dan ekstrak antosianin, serta emulsifier yang digunakan. 


\section{DAFTAR PUSTAKA}

[AOAC] Association of Official Analytical Chemists. 2012. Official Methods of Analysis of the Association of Official Analytical Chemist $19^{\text {th }}$ Edition. Association of Official Analytical Chemists, Washington DC USA.

Balbinot-Alfaro E, Craveiro DV, Lima KO, Costa HLG, Lopes DR, Prentice C. 2019. Intelligent packaging with $\mathrm{pH}$ indicator potential. Food Eng Rev 11: 235-244. DOI: 10.1007/s12393-01909198-9.

Bourtoom T, Chinnan MS. 2009. Improvement of water barrier property of rice starch-chitosan composite film incorporated with lipids. Revista de Agaroquimica y Tecnologia de Alimentos 15: 149-158. DOI: 10.1177/1082013208105993.

Chambi HNM, Grosso CRF. 2011. Mechanical and water vapor permeability properties of biodegradables films based on methylcellulose, glucomannan, pectin and gelatin. Ciênc Tecnol Aliment 31: 739-746. DOI: 10.1590/S0101-2061 2011000300029.

Chaovanalikit A, Apichayaluk S, Kongtong S, Chuprathum S. 2009. Effect of $\mathrm{pH}$ and temperature on the stability and visual color of roselle and butterfly pea extracts. Agric Sci J 40: 5-8.

Choi I, Lee JY, Lacroix M, Han J. 2017. Intelligent $\mathrm{pH}$ indicator film composed of agar/potato starch and anthocyanin extracts from purple sweet potato. Food Chem 218: 122-128. DOI: 10.1016/j.foodchem.2016.09.050.

Denavi GA, Pérez-Mateos M, Añón MC, Montero P, Mauri AN, Gomez-Guillen MC. 2009. Structural and functional properties of soy protein isolate and cod gelatin blend films. Food Hydrocolloid 23: 2094-2101. DOI: 10.1016/j.foodhyd.2009. 03.007.

Faseha A, Rawdkuen S. 2016. Intelligent gelatin film using anthocyanin as color indicator. J Food Sci Agric Technol 2: 1-11.

Hanani ZN, Roos YH, Kerry JP. 2012. Use of beef, pork and fish gelatin sources in the manufacture of films and assessment of their composition and mechanical properties. Food Hydrocolloid 29: 144-151. DOI: 10.1016/j.foodhyd. 2012.01.015.

Ibraheem NA, Hasan, MM, Khan RZ, Mishra PK. 2012. Understanding color models - a review. ARPN J Sci Technol 2: 265-275.

Kaci M, Arab-Tehrany E, Desjardins I, Banon-Desobry S, Desobry S. 2017. Emulsifier free emulsion: Comparative study between a new high frequency ultrasound process and standard emulsification processes. J Food Eng 194: 109118. DOI: 10.1016/j.jfoodeng.2016.09.006.

Kadam SU, Pankaj SK, Tiwari BK, Cullen PJ, O'Donnell CP. 2015. Development of biopolymer-based gelatin and casein films incorporating brown seaweed Ascophyllum nodosum extract. Food Packaging Shelf Life 6: 68-74. DOI: 10.1016/j.fpsl.2015.09.003.

Kaewprachu P, Rawdkuen S. 2014. Mechanical and physico-chemical properties of biodegradable protein-based films: A comparative study. Food App Biosci J 29: 15-30. DOI: 10.14456/fabj. 2014.2.

Kaewprachu P, Osako K, Benjakul S, Suthiluk P, Rawdkeun S. 2017. Shelf life extension for Bluefin tuna slices (Thunnus thynnus) wrapped with myofibrillar protein film incorporated with catechin-Kradon extract. Food Control 79: 333343. DOI: 10.1016/j.foodcont.2017.04.014.

Khoo HE, Azlan A, Tang ST, Lim SM. 2017. Anthocyanidins and anthocyanins: colored pigments as food, pharmaceutical ingredients, and the potential health benefits. Food Nutr Res 61: 121. DOI: 10.1080/16546628.2017.1361779.

Limpan N, Prodpran T, Benjakul S, Prasarpan S. 2010. Properties of biodegradable blend films based on fish myofibrillar protein and polyvinyl alcohol as influenced by blend composition and pH level. J Food Eng 100: 85-92. DOI: 10.1016/ j.jfoodeng.2010.03.031.

Limpisophon K, Tanaka M, Osako K. 2010. Characterisation of gelatin-fatty acid emulsion films based on blue shark (Prionace glauca) skin gelatin. Food Chem 122: 1095-1101. DOI: 10.1 016/j.foodchem.2010.03.090.

Luchese CL, Garrido T, Spada, JC, Tessaro IC, de la Caba K. 2018. Development and characterization of cassava starch films incorporated with blueberry pomace. Int $\mathrm{J}$ Biol Macromol 106: 834-839. DOI: 10.1016/j.ijbiomac.2017.08.083.

Ma W, Tang $\mathrm{CH}$, Yin SW, Yang XQ, Wang Q, Liu F, Wei ZH. 2012a. Characterization of gelatinbased edible films incorporated with olive oil. Food Res Int 49: 572-579. DOI: 10.1016/j. foodres.2012.07.037.

Ma W, Tang CH, Yin SW, Yang XQ, Qi JR, Xia N. 2012b. Effect of homogenization conditions on properties of gelatin-olive oil composite films. J Food Eng 113: 136-142. DOI: 10.1016/j.jfood eng.2012.05.007.

Ma Q, Hu D, Wang H, Wang L. 2016. Tara gum edible film incorporated with oleic acid. Food Hydrocolloid 56: 127-133. DOI: 10.1016/j.food hyd.2015.11.033. 
Mahmudatussa'adah A, Fardiaz D, Andarwulan N, Kusnandar F. 2014. Karakteristik warna dan aktivitas antioksidan antosianin ubi jalar ungu. J Teknol Industri Pangan 25: 176-184. DOI: 10.6066/jtip.2014.25.2.176.

Musso YS, Salgado PR, Mauri AN. 2017. Smart edible films based on gelatin and curcumin. Food Hydrocolloid 66: 8-15. DOI: 10.1016/j.food hyd.2016.11.007.

Pelissari FM, Andrade-Mahecha MM, Sobral PJDA, Menegalli FC. 2012. Isolation and characterization of the flour and starch of plantain bananas (Musa paradisiaca). Starch-Stärke 64: 382391. DOI: 10.1002/star.201100133.

Pereira VA, de Arruda INQ, Stefani R. 2015. Active chitosan/PVA films with anthocyanins from Brassica oleraceae (red cabbage) as time-temperature indicators for application in intelligent food packaging. Food Hydrocolloid 43: 180188. DOI: 10.1016/j.foodhyd.2014.05.014.

Prietto L, Mirapalhete TC, Pinto VZ, Hoffmann JF, Vanier NL, Lim LT, Dias ARG, Zavareze EDR. 2017. pH-sensitive films containing anthocyanins extracted from black bean seed coat and red cabbage. LWT-Food Sci Technol 80: 492500. DOI: 10.1016/j.Iwt.2017.03.006.

Pradini D, Juwono $H$, Madurani KA, Kurniawan $F$. 2018. A preliminary study of identification halal gelatin using quartz crystal microbalance (QCM) sensor. Malaysian J Fundamental Appl Sci 14: 325-330. DOI: 10.11113/mjfas.v14n3.9 42.

Raghvendra, Sharma V, Shakya A, Hedaytullah MD, Arya GS, Mishra A, Gupta AD, Pachpute AP, Patel D. 2011. Chemical and potential aspects of anthocyanins-a water-soluble vacuolar flavonoid pigments - a review. Int J Pharm Sci Rev Res 6: 28-33.

Rattaya S, Benjakul S, Prodpran T. 2009. Properties of fish gelatin film incorporated with seaweed extract. J Food Eng 95: 151-157. DOI: 10.1016/j.jfoodeng.2009.04.022.
Robertson GL. 2013. Food Packaging: Principles and Practice. 414-421. CRC Press, Boca Raton.

Rocca-Smith JR, Marcuzzo E, Karbowiak T, Centa J, Giacometti M, Scapin F, Venir E, Sensidoni A, Debeaufort F. 2016. Effect of lipid incorporation on functional properties of wheat gluten based edible films. J Cereal Sci 69: 275-282. DOI: 10.1016/j.jcs.2016.04.001.

Stoll L. 2015. Development and application of active biodegradable films with antioxidants extracted from wine grape pomace [Thesis]. Porto Alegre (Brasil): Instituto De Ciência E Tecnologia De Alimentos, Universidade Federal Do Rio Grande Do Sul.

Tongnuanchan P, Benjakul S, Prodpran T. 2013. Characteristics and antioxidant activity of leaf essential oil-incorporated fish gelatin films as affected by surfactants. Int J Food Sci Technol 48: 2143-2149. DOI: 10.1111/ijfs. 12198.

Tongnuanchan P, Benjakul S, Prodpran T, Nilsuwan K. 2015. Emulsion film based on fish skin gelatin and palm oil: Physical, structural, and thermal properties. Food Hydrocolloid 48: 248-259. DOI: 10.1016/j.foodhyd.2015.02.025.

Wang S, Marcone M, Barbut S, Lim LT. 2012. The impact of anthocyanin-rich red raspberry extract (ARRE) on the properties of edible soy protein isolate (SPI) films. J Food Sci 77: C497-C505. DOI: 10.1111/j.1750-3841.2012.02655.x.

Wang Z, Zhou J, Wang $X X$, Zhang $N$, Sun $X X$, Ma ZS. 2014. The effects of ultrasonic/microwave assisted treatment on the water vapor barrier properties of soybean protein isolate-based oleic acid/stearic acid blend edible films. Food Hydrocolloid 35: 51-58. DOI: 10.1016/j.food hyd.2013.07.006.

Zhang X, Lu S, Chen X. 2014. A visual pH sensing film using natural dyes from Bauhinia blakeana Dunn. Sensor Actuat B: Chem 198: 268-273. DOI: 10.1016/j.snb.2014.02.094. 